\title{
The scenic rim of southeastern Queensland, Australia: A history of mid Cenozoic intraplate volcanism
}

School of Earth Sciences, The University of Queensland, Brisbane, QLD 4072, Australia. E-Mail: b.cohen@uq.edu.au

Intraplate volcanism was widespread in southeastern Queensland during the mid Cenozoic, leaving a legacy of variably eroded volcanoes and rugged topography known locally as "The Scenic Rim". These plume-derived volcanoes provide a detailed record of northward Australian plate velocity, and indicate a major slowdown commencing at $26 \mathrm{Ma}$ and persisting until $23 \mathrm{Ma}$, correlated with initial collision of the massive Ontong Java plateau with the northern subduction margin of the Australian plate. Despite traversing over $36 \mathrm{~km}$ of continental crust, trace element and isotopic signatures indicate little or only minor contamination for most units, with the exception of rhyolites formed during the period of slow plate velocity. Nevertheless, the thick continental crust allowed magmas to stall and fractionate during ascent, often producing highly evolved rocks (e.g., comendites) containing extreme concentrations of incompatible elements, including >2000 ppm Zr. Meanwhile, isotopic and trace element results from mafic units are consistent with melting and mixing of depleted upper mantle and an EMI-like source. Alkaline mafic eruptions also often contain abundant upper mantle and lower crustal xenoliths, providing excellent samples of these otherwise inaccessible regions. Denudation has produced good exposures of the subsurface magmatic architecture, a variety of landscapes, and diverse wildlife habitats; as a result many of the volcanoes are contained in National Parks, including the World Heritage listed Gondwana Rainforests of Australia.

\section{Introduction}

Australia is located in the centre of its tectonic plate, and has a widespread public image of being "a wide and sunburnt country" that is geologically all but dead (e.g., Bryson, 2000). Nevertheless, the Cenozoic history of the continent is not as quiet as is often assumed. Instead, eastern Australia is the site of one of the most extensive intraplate volcanic regions on the globe, with the products of volcanism extending over $4,000 \mathrm{~km}$, covering a present-day area of 1.6 million $\mathrm{km}^{2}$ (Figure 1a) (Johnson, 1989). Eruptions occurred throughout the Cenozoic (Wellman and McDougall, 1974; Vasconcelos et al., 2008), with the most recent activity as little as 4.3 kya (Blackburn et al., 1982; Robertson et al., 1996).

The products of intraplate volcanism were particularly abundant in SE Queensland during the mid Cenozoic, extending over the state border into New South Wales (Figures 1 and 2). The largest Cenozoic volcanoes on the continent are located in this region; the Main Range volcano is over $80 \mathrm{~km} \mathrm{~N}-\mathrm{S}$, and Tweed has a diameter of c. $100 \mathrm{~km}$ (Figure 1b). This region also hosts some of the greatest diversity of magma types found in eastern Australia, and an unusually large volume of highly fractionated rhyolites (Ewart et al., 1985; Ewart and Grenfell, 1985; Ewart et al., 1988). Erosion of the volcanoes has produced a wide range of spectacular landforms, exposed the magmatic plumbing systems, and resulted in a variety of habitats and ecosystems (Figures 3, 4) (Hunter, 2004). These factors make SE Queensland and northern New South Wales some of the most important intraplate volcanic zones on the continent. This paper reviews the chronology, petrology, and geomorphology of volcanism in this region.

\section{Time-space distribution of volcanism, and the plate tectonic record}

Eastern Australia is an ideal natural laboratory to investigate the origins of intraplate volcanism, as three types of volcano are recognised (Figure 1): central volcanoes, lava fields, and leucitites, with each type displaying differences in morphology, chronology, and chemistry (Wellman and McDougall, 1974; Johnson, 1989). Central volcanoes comprise a central zone of silicic intrusions and flows, surrounded by a variably eroded shield of mafic lavas (Wellman and McDougall, 1974; Cas, 1989). Lava field provinces, in contrast, are comprised almost exclusively of mafic rocks (Wellman and McDougall, 1974; Ewart, 1989), and are generally aerially extensive and thin, although piles up to $1000 \mathrm{~m}$ thick were formed in some early Cenozoic cases (Cas, 1989). Leucitites are volumetrically minor, comprising a cumulative total of $<3 \mathrm{~km}^{3}$ scattered over small outcrops in inland New South Wales and Victoria (Figure 1) (Wellman and McDougall, 1974; Cohen et al., 2008).

There are no well-defined time-space groupings or progressions for lava field eruptions, with ages spanning from Late Mesozoic to Holocene (Wellman and McDougall, 1974; Johnson, 1989; Vasconcelos et al., 2008). A variety of formation mechanisms have been proposed (e.g., Lister and Etheridge, 1989; Sutherland, 1991, 


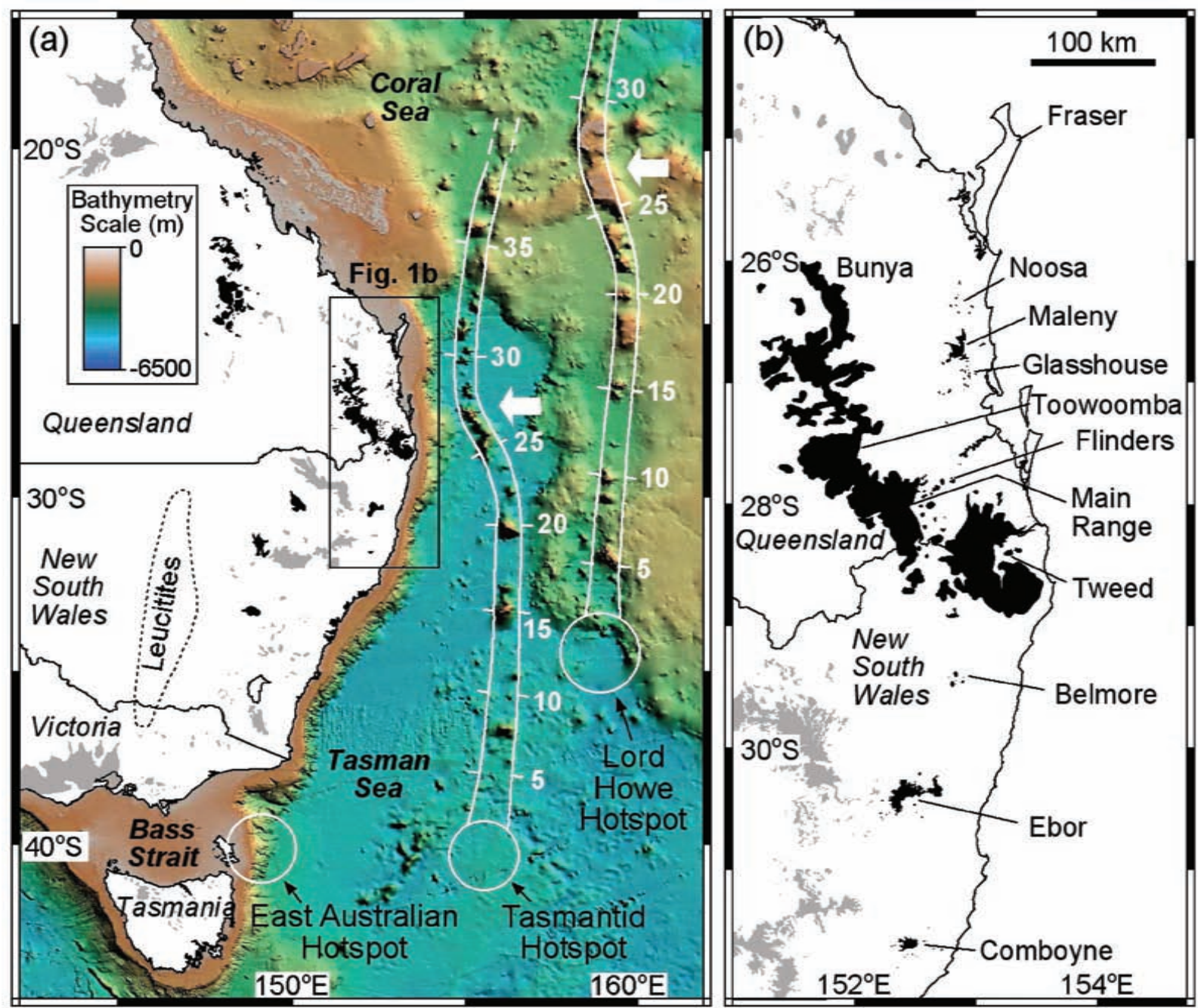

Figure 1 Widespread intraplate volcanism in a) the Australian region and b) SE Queensland. Central volcanoes are black; lava fields are grey (after Knesel et al., 2008).

1992, 1993; Demidjuk et al., 2007; Conrad et al., 2011) although none of these models explain the complete spectrum of spatial, geochemical, and temporal features of the lava fields (see Johnson, (1989) and Vasconcelos et al., (2008) for reviews).

Central volcanoes, on the other hand, become progressively younger towards the $\mathrm{S}$, and record the northward velocity of the Australian plate over a mantle plume that is presently located beneath Bass Strait (Figure 1a) (Wellman and McDougall, 1974; Knesel et al., 2008). Plume-derived volcanism also occurs offshore, with two age-progressive seamount trails in the seas E of the continent (Figure 1a) (McDougall and Duncan, 1988; Quilty, 1993). Leucitite ${ }^{40} \mathrm{Ar} /{ }^{39} \mathrm{Ar}$ ages are similar to the adjacent central volcanoes, and also become younger to the $\mathrm{S}$, consistent with a hotspot-related origin (Cohen et al., 2008).

In SE Queensland central volcanoes dominate, with only minor occurrences of lava field eruptions (Figure 1b). ${ }^{40} \mathrm{Ar} /{ }^{39} \mathrm{Ar}$ geochronology of these central volcanoes indicates that shield-forming mafic eruptions occurred over a protracted period of 3-5 Myr, whereas the silicic units were emplaced within $\leq 1 \mathrm{Myr}$, towards the end of the main period of mafic activity (Cohen et al., 2007; Knesel et al., 2008). As such, the silicic rocks provide consistent and distinctive markers in the history of central-volcano activity, allowing detailed age comparisons to be made between volcanoes.
${ }^{40} \mathrm{Ar} /{ }^{39} \mathrm{Ar}$ ages for these silicic units become younger towards the $\mathrm{S}$, but this migration was not constant, with a $>50 \%$ decrease in migration rate occurring from 26 until $23 \mathrm{Ma}$ (Figure 2). At the same time, the Tasmantid and Lord Howe seamount chains have abrupt and brief changes in direction, with a distinct NW trend from 26$23 \mathrm{Ma}$ (indicated by the large white arrows in Figure 1) that is in sharp contrast to the NNE trends before c. 26 and after c. $23 \mathrm{Ma}$ (Knesel et al., 2008). Plate tectonic modelling shows that the Tasmantid hotspot was fixed relative to the Pacific hotspot reference frame for at least the last $40 \mathrm{Ma}$ (Gaina and Müller, 2000), indicating that the bends in the seamount chains (Figure 1) reflect changes in Australian plate motion. In addition, paleomagnetic analyses of the Main Range and Tweed volcanoes also demonstrate a westward plate excursion at this time (McElhinny et al., 1974; Wellman, 1975). Taken together, these pieces of evidence indicate that during the mid Cenozoic, the Australian plate underwent abrupt and brief changes in plate velocity, from fast NNE velocity prior to $26 \mathrm{Ma}$, to slow NW motion between $26-23 \mathrm{Ma}$, and recovering to fast NNE velocity after $23 \mathrm{Ma}$ (Knesel et al., 2008).

This transient 'crash' in Australian plate velocity is correlated to oblique collision of the Australian plate with the massive (Greenlandsized) Ontong Java plateau, which sits on the Pacific plate (Knesel et al., 2008). This collision acted to cease $\mathrm{N}$-dipping subduction of the 


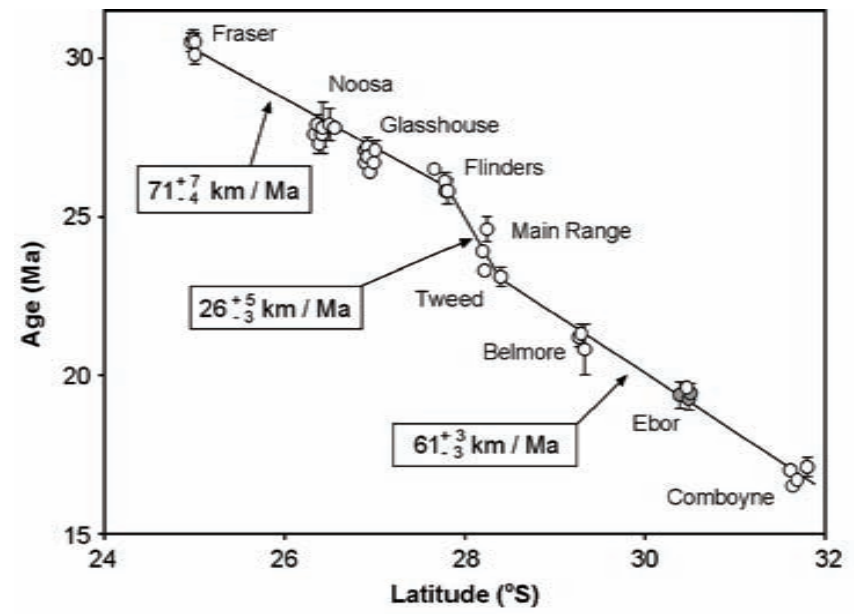

Figure 2 Ages for the volcanoes become steadily younger towards the $S$, tracking the Australian plate velocity over a mantle plume (after Knesel et al., 2008).

Australian plate (Knesel et al., 2008) and also changed the motion of the Pacific plate, as indicated by bends of the same age in Pacific seamount trails, including the Hawaiian and Louisville chains (Kroenke et al., 2004). The high-resolution ${ }^{40} \mathrm{Ar} /{ }^{39} \mathrm{Ar}$ study of Australian central volcanoes by Knesel et al. (2008) demonstrates the power of such analyses in investigating plate-tectonic and geodynamic processes, as also exemplified by geochronologic analyses of other intraplate volcanic chains (e.g., Koppers et al., 2004; Sharp and Clague, 2006).

\section{Magma petrogenesis: influence of changing plate velocity, and interaction of plume-derived magmas with continental lithosphere}

In addition to these tectonic observations, the Australian central volcanoes also provide an excellent case study of plume-derived magmas interacting with the continental lithosphere. Lavas erupted in SE Queensland and northern New South Wales include tholeiitic basalts, mildly alkaline basalts, highly alkaline mafic units (e.g., nepheline hawaiites, leucite basanites), and highly evolved silicic units (metaluminous trachytes, peralkaline rhyolites, and peraluminous rhyolites) (Ewart et al., 1980; Ewart et al., 1985; Ewart and Grenfell, 1985). Intrusive equivalents are also present. This magmatic diversity reflects the influence of different mantle reservoirs, degrees of partial melting, fractional crystallisation, and crustal contamination, as reviewed below. The changes in plate velocity (Figure 2) also affected the characteristics of volcanism in the region.

The Tweed and Main Range volcanoes (i.e., those erupted during the 26-23 Ma period of slow plate velocity; Figure 2) have been recognised as being both anomalously large and containing an unusually high abundance of rhyolitic rocks (e.g., Ewart et al., 1987; Duggan et al., 1993). These two edifices cover a substantially larger area than other central volcanoes (Figure 1), and have a correspondingly greater volume - between $3,000-4,000 \mathrm{~km}^{3}$ in the case of Tweed, compared to $10-800 \mathrm{~km}^{3}$ for other central volcanoes (Duncan and McDougall, 1989). Rhyolitic rocks at these volcanoes also have trace element and isotopic signatures that are indicative of
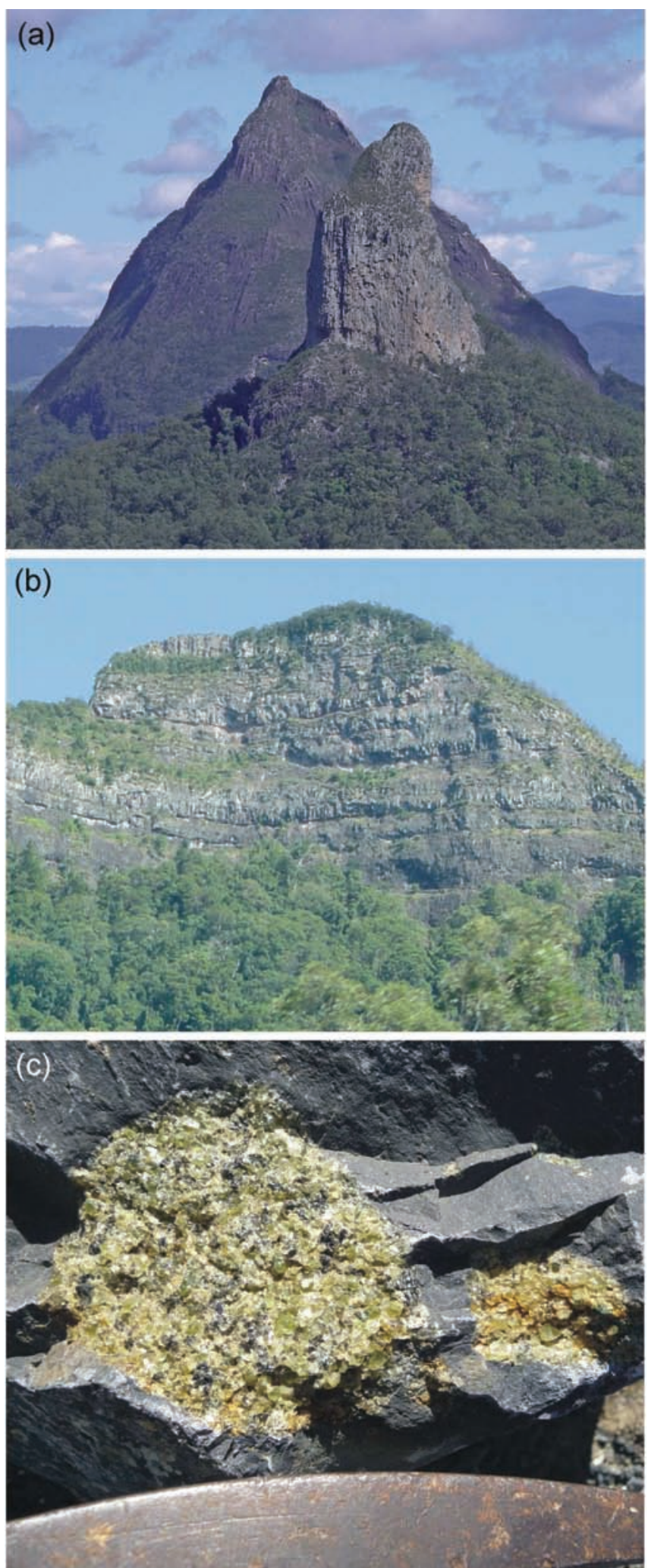

Figure 3 Representative field photographs: (a) The Glasshouse Mountains, looking W towards Mt Coonowirin (foreground, $377 \mathrm{~m}$ elevation) and Mt Beerwah (background, $556 \mathrm{~m}$ elevation). Both peaks feature very large cooling columns (Photo courtesy of Warwick Willmott). (b) Excellent stratigraphic exposure of mafic lavas at Mt Mitchell in the Main Range volcano. (c) Ultramafic xenoliths at Euston Road Quarry, Toowoomba (hammer for scale). 


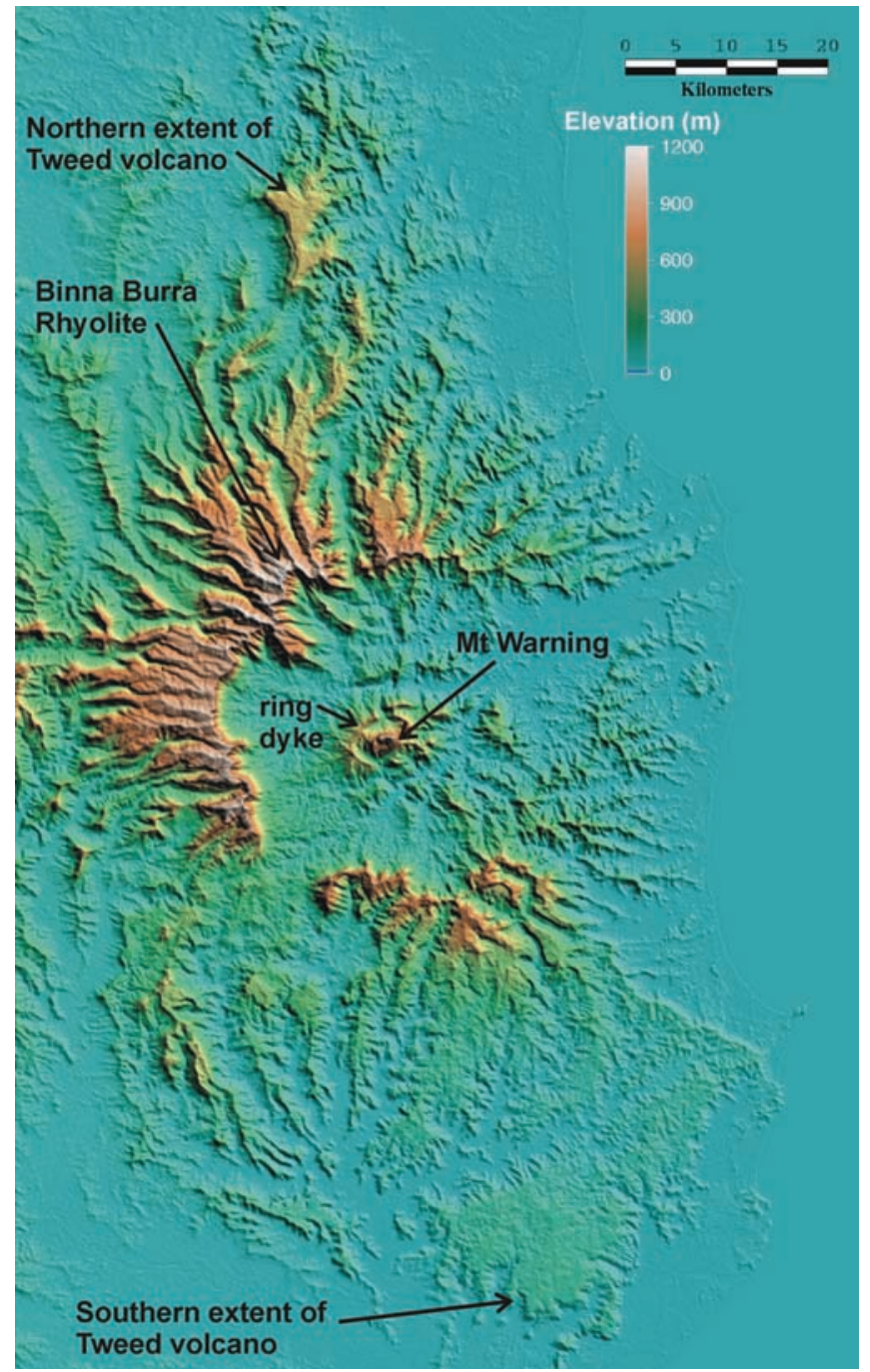

Figure 4 Digital elevation model of the Tweed volcano showing the original shield shape, with erosion exposing the subvolcanic intrusive complex that is centered on Mt Warning, and surrounded by ring dykes.

substantial crustal melting or contamination, including high $\left({ }^{87} \mathrm{Sr} /\right.$ $\left.{ }^{86} \mathrm{Sr}\right)_{\text {initial }}$ values (Figure 5). Such high amounts of crustal influence are not commonly recognised in volcanoes erupted outside the 2623 Ma period; the implication is that the slower plate velocity, and therefore longer time over the mantle plume, allowed the construction of larger volcanoes, as well as promoting increased melting of the crust (Knesel et al., 2008).

Other than the abovementioned rhyolites from Tweed and Main Range, trace element and isotopic $(\mathrm{Pb}, \mathrm{Sr}, \mathrm{Nd}, \mathrm{O})$ values indicate minimal or no crustal contamination for silicic and mafic magmas (Ewart, 1982; Ewart et al., 1988). This is illustrated by the $\mathrm{Sr}$ and $\mathrm{Nd}$ isotopic signatures of trachytic and rhyolitic rocks (excluding those from Tweed and Main Range), which largely overlap with the values for the mafic lavas and are isotopically similar to the oceanic Pitcairn hotspot (Figure 5).

Continental crust in SE Queensland is c. $36 \mathrm{~km}$ thick, with a further $6-10 \mathrm{~km}$ of strong coherent reflecting horizons representing the transitional zone to the mantle (van der Hilst et al., 1998). Although evidently only providing minimal material contribution to most magmas (Figure 5), this thick buoyant continental lithosphere

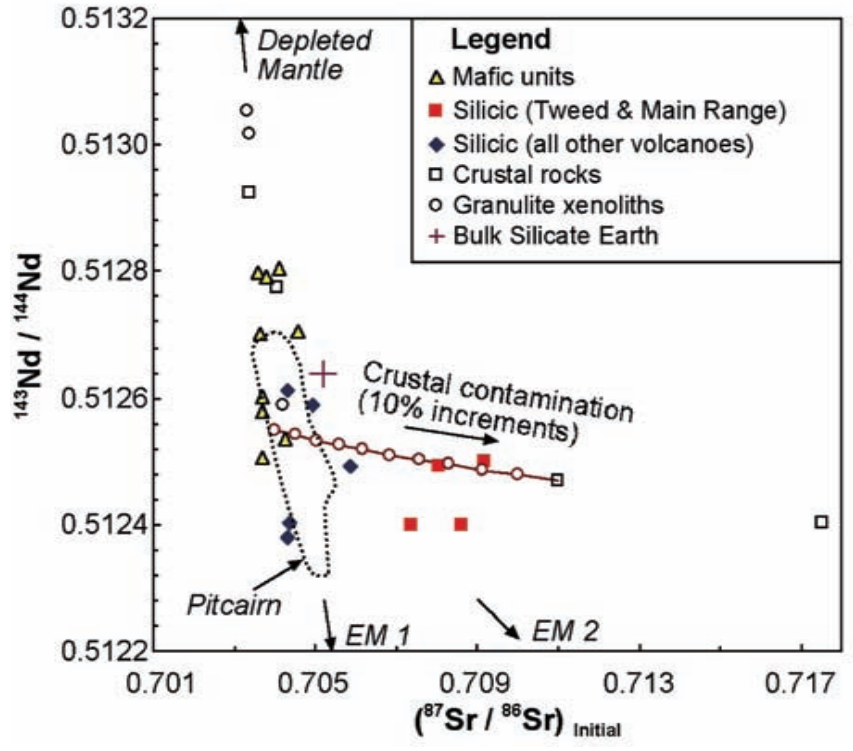

Figure $5 \mathrm{Sr}$ vs. Nd isotopes for lavas, granulite xenoliths, and crustal materials in SE Queensland (data from Ewar, 1982 and Ewart et al. 1988). Isotopic data from the EM1 hotspot at Pitcairn (Eisele et al., 2002) shown for comparison.

still influenced the magma petrogenesis by acting as a substantial barrier to the upward transport of magmas. Most major and trace element trends point to variable amounts of fractional crystallisation (Ewart et al., 1985). In some cases, particularly for the peralkaline rhyolites, extreme degrees of fractional crystallisation are indicated, with greater than $2000 \mathrm{ppm} \mathrm{Zr}$ and $400 \mathrm{ppm} \mathrm{Rb}$ recorded - but $<1$ ppm Sr - indicating extreme enrichments and depletions of incompatible and compatible elements, respectively (Ewart et al., 1985; Ewart and Grenfell, 1985). Rare earth element concentrations are also enriched in these rocks; one peralkaline rhyolite from the Glasshouse Mountains has a La concentration over 700 times that of chondritic meteorites (Figure 6). The rhyolitic rocks also have considerable Europium anomalies $\left(\mathrm{Eu} / \mathrm{Eu}^{*}\right.$ as low as 0.0023 for the Binna Burra rhyolite from the Tweed volcano; Figure 6), which can be reproduced by a feldspar-dominated fractionation assemblage (Ewart et al., 1985). These extreme degrees of fractional crystallisation have resulted in distinctive mineralogical assemblages, including low $\mathrm{Ca}$-anorthoclase, $\mathrm{Zr}$-aegirine, fluor-ardvedsonite, \pm aenigmatite, \pm fayalite, \pm hedenbergite, and high-Zn ilmenite (Ewart, 1985).

As a result of extensive fractional crystallisation processes, as well as crustal melting, the various silicic rocks comprise on average c. 30 volume \% of the central volcanoes (Wellman, 1971) - a much higher percentage than typically observed at oceanic intraplate islands (e.g., Clague, 1987). Nevertheless, mafic lavas still comprise the bulk of the volcanic products. Variations in trace element and isotopic data among central-volcano basalts in SE Queensland, and elsewhere in eastern Australia, indicate mixing between two distinct source components: an EM1-like source and a depleted upper-mantle source (Figure 5) (McDonough et al., 1985; Ewart et al., 1988; Sun et al., 1989). In some models, the enriched-mantle signature has been interpreted to arise from interaction of plume-derived melts with the subcontinental lithosphere (e.g., McDonough et al., 1985; Ewart et al., 1988; Sun et al., 1989). However, EM1 signatures have also been recorded from the Tasmantid seamounts (Eggins et al., 1991), which sit on oceanic crust, suggesting the EM1 signature may derive directly 


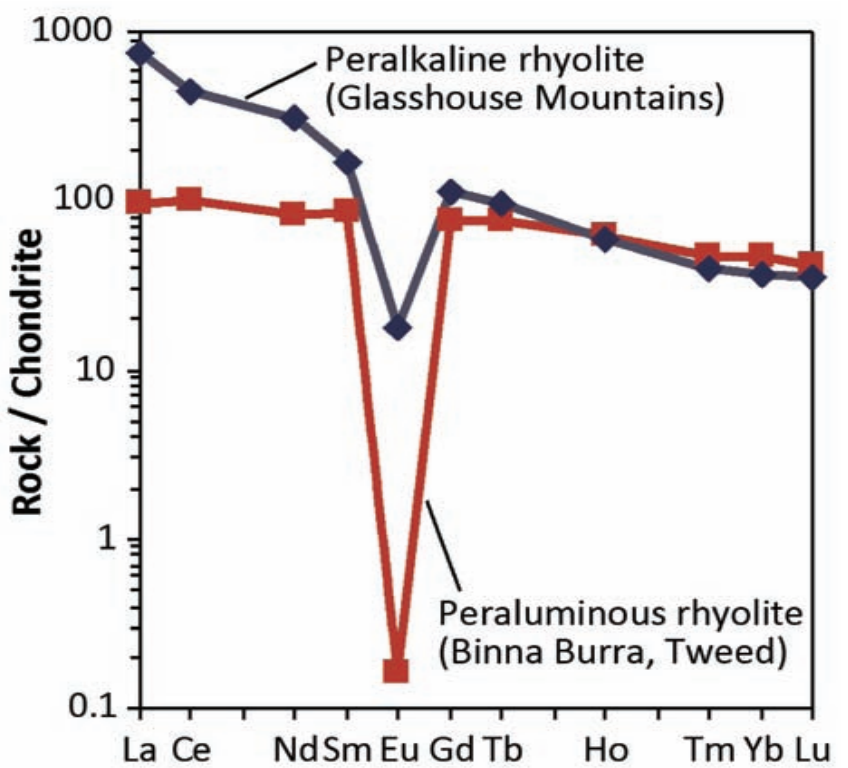

Figure 6 Chondrite-normalised rare earth element patterns for a comendite from the Glasshouse Mountains, and the Binna Burra high-silica rhyolite from the Tweed volcano (data from Ewart et al., 1985).

from the plume. The exact source of the EM1 signature therefore remains unresolved. An important - but as yet unused - mechanism to investigate the isotopic systematics of the lithospheric mantle beneath SE Queensland is provided by the abundant xenoliths and megacrysts in this region, which are described below.

\section{Xenoliths, megacrysts, and alkaline mafic eruptions}

Cenozoic volcanoes in eastern Australia have yielded a rich record of xenoliths and megacrysts (O'Reilly and Griffin, 1987) and SE Queensland is no exception, with the Toowoomba and Main Range areas being especially prolific (Figure 3c) (Green et al., 1974; Ewart and Grenfell, 1985; O'Reilly and Griffin, 1987; Sutherland et al., 1990). These inclusions are hosted in silica-undersaturated mafic eruptions of hawaiite, olivine nephelenite, nepheline hawaiite, nepheline benmoreite, leucite basanite, and camptonite (Ewart and Grenfell, 1985). These alkaline eruptions typically commenced with an initial explosive phase producing tuff and breccia, with subsequent more effusive lavas filling the earlier-formed vent (Willey, 2003). These eruptions clearly crosscut or overlie earlier phases of activity, and ${ }^{40} \mathrm{Ar} /{ }^{39} \mathrm{Ar}$ geochronology of one such eruption from Main Range indicates eruption $3 \mathrm{Ma}$, after the bulk of the volcano was constructed (Knesel et al., 2008); a timeframe analogous to the postshield- and rejuvenated-stage eruptions on the Hawaiian Islands (Clague, 1987).

Xenolith phases recorded in SE Queensland are dominantly from the upper mantle or lower crust, comprising: Cr-spinel lherzolite, clinopyroxenite, wehrlite, websterite, kaersutite pyroxenite, metasomatised clinopyroxenite, hornblendite, meladiorite, twopyroxene granulite, and gabbro (Ewart and Grenfell, 1985; Sutherland et al., 1990). Megacrysts have also been recovered, comprising: Ti-Al augite, orthopyroxene, feldspar, garnet, kaersutite, mica, and Fe-Ti oxides, as have a small number of accidental upper-crustal xenoliths (e.g., quartzite, granite) (Ewart and Grenfell, 1985; Sutherland et al., 1990).
Given the volumetric abundance of each xenolith type, these xenolith suites indicate the upper mantle in SE Queensland is dominated by spinel lherzolite, with a granulitic lower crust (Ewart and Grenfell, 1985; Sutherland et al., 1990). Only spinel lherzolites have been recorded in SE Queensland, although garnet lherzolites are found elsewhere in Australia (O'Reilly and Griffin, 1985; Griffin et al., 1987). The east Australian xenolith suites define a paleogeothermal gradient that is substantially hotter than is typical for continental regions (O'Reilly and Griffin, 1985; Griffin et al., 1987). However, no trace elemental or isotopic studies have been undertaken on the ultramafic xenoliths in SE Queensland, which could yield information on the composition of the sublithospheric mantle in this region. As such, this is a prime research target awaiting further investigation.

\section{Volcanic geomorphology}

Despite erosion since the mid Cenozoic, the shield structure is still apparent in some volcanoes, with the original surfaces remaining as elevated plateaux that are cut by a series of radial streams. The Tweed volcano is an excellent example, with the shield flanks remaining on the northern, western, and southern sides (Figure 4). Bunya also retains a shield shape, while Toowoomba and Main Range have only the western flanks preserved (Ewart and Grenfell, 1985). Coastal erosion has progressed further at Noosa and GlasshouseMaleny, with only small expanses of mafic lava remaining (Figure 1) (Cohen et al., 2007). Meanwhile, in the case of Fraser, the only remaining volcanic outcrops are three isolated headlands comprised of trachytic lavas cut by mafic dykes, which are completely surrounded by Quaternary sand (Cohen et al., 2007). At this volcano, all other volcanic units have either been eroded, or exist below sea level (Grimes, 1982).

Although removing the original mafic shield, this erosion has enabled excellent exposure of the stratigraphy and subsurface architecture of the volcanoes, often also producing spectacular scenery (Figure 3a, b). At the Tweed volcano this erosion has revealed the magmatic plumbing system beneath the shield (Figure 4), which comprises an intrusive complex of gabbros, syenite, granite, and comendite (Duggan et al., 1993). Circular ring dykes surround the complex, and form significant relief (Figure 4). The intrusive complex extends from almost sea level to a maximum elevation of $1159 \mathrm{~m}$ at the summit of Mt Warning, revealing a wide range of intrusive environments. A large subvolcanic intrusive complex also exists at Mt Barney in the southern Main Range volcano (sometimes called the Focal Peak volcano, e.g., Ewart et al., 1987).

Other volcanoes in SE Queensland apparently lack a single main subvolcanic intrusion, instead containing multiple plugs, sills, dykes, and laccoliths. The Glasshouse Mountains are an excellent example, where over 15 eroded hypabyssal plugs and laccoliths rise abruptly from the coastal plain (e.g., Figure 3a). Numerous subvolcanic plugs are also present in the Fassifern Valley E of Main Range, and in the Noosa region (Ewart and Grenfell, 1985; Cohen et al., 2007).

The rugged eroded volcanic landforms are the most prominent geographic landmarks in SE Queensland. As a result, the volcanoes feature in Aboriginal legends, and were also observed by early European explorers. Mt Warning, the prominent core of the Tweed volcano (Figure 4), was sighted on the 16th of May 1770 by the British explorer, James Cook, and named as a warning to subsequent mariners of dangerous shoals that exist off the coast in this region 
(Hawkesworth, 1773). This peak, also known as Wollumbin, is sacred for the Bundjalung Aboriginal people. Further N, the Glasshouse Mountains were named by Cook on the 17th of May 1770, who described the peaks as "very remarkable on account of there [sic] singlar [sic] form of elevation which very much resemble glass houses which occasioned my giving them that name" (Hawkesworth, 1773). The peaks themselves are known after characters in a Dreamtime story of the Gubbi Gubbi (or Kabi) people, with distinctive names such as Miketeebumulgrai, Coochin, Beerburrum, Ngungun, Tibrogargan, Coonowrin, and Beerwah.

\section{Volcanic influence on flora, fauna, and human land-use}

The rock types and geomorphology of the volcanoes also significantly influence the vegetation and land use patterns in this region. Volcanic plateaus underlain by mafic lavas have fertile soils, supporting dense subtropical rainforests, especially in regions with greater rainfall (Willmott, 2003; Hunter, 2004). In contrast, regions underlain by rhyolite have poorer soils, and wet or dry sclerophyll eucalypt forests have developed, adding to the biodiversity of the region (Willmott, 2003; Hunter, 2004). Steep and inaccessible areas frequently remain uncleared, and, as a result of rugged scenery and diverse biology, many of the volcanic regions have been protected as National Parks, which are important tourist attractions in the region. Of particular significance are those parks on either side of the New South Wales/Queensland state border, which are part of the World Heritage listed "Gondwana Rainforests of Australia" (formerly the "Central Eastern Rainforest Reserves of Australia", Hunter, 2004).

Meanwhile, some fertile regions developed on mafic lavas were cleared for farming, especially on the Maleny plateau, around Toowoomba, and the flanks of the Tweed volcano. Where cleared, steep slopes are subject to landslides, a hazard that has increased in recent years as the volcanic regions become increasingly attractive for residential and rural housing (Willmott, 2010). Volcanic rocks are quarried for road and concrete aggregate, boulder stone, perlite (hydrated volcanic glass), as well as diatomite from sediments deposited between flows. Quarries in mafic plugs are particularly common around Toowoomba (Willey, 2003). Some rhyolite or trachyte plugs around Noosa, the Glasshouse Mountains, and Main Range have also been exploited, but most of these quarries are now inactive. In all cases, quarrying is limited by the often-steep volcanic terrain, preservation in National Parks, and by the increasing urbanisation of SE Queensland.

\section{Conclusions}

The mid-Cenozoic volcanoes in SE Queensland provide a valuable record of intraplate volcanic activity on continental Australia. The time-space distribution of the volcanoes indicate a major reduction of northward Australian plate velocity from 26-23 Ma, correlated to initial collision of the massive Ontong Java plateau with the northern subduction margin of the Australian plate. The rocks also record the interaction of the plume-derived magmas with continental lithosphere, with varying degrees of melting, fractionation, and crustal contamination producing a wide variety of magmas. Erosion of the volcanoes has created diverse rugged landscapes with excellent exposures of subvolcanic magmatic systems. These eroded volcanoes also host considerable biodiversity, and the volcanic landforms feature prominently in both Aboriginal legends and the early European exploration of the region. As a consequence of this varied geologic, biologic, and human history, these volcanoes represent important sights of research and tourism, both in the past and into the future.

\section{Acknowledgements}

I would like to thank Paulo Vasconcelos and Kurt Knesel for discussions and research support during the work on Cenozoic volcanism in eastern Australia, Tony Ewart and Ian McDougall for their constructive reviews, David Thiede for reading an earlier version of the text, and the editors of this special issue of Episodes for the opportunity to present this manuscript.

\section{References}

Blackburn, G., Allison, G.B. and Leaney, F.W.J., 1982, Further evidence on the age of the tuff at Mt Gambier, South Australia: Royal Society of South Australia, Transactions, v. 106, pp. 163-167.

Bryson, B., 2000, Down Under: Doubleday, London, 319 pp.

Cas, R.A.F., 1989, Physical Volcanology, in Johnson, R.W. (ed), Intraplate Volcanism in eastern Australia and New Zealand: Cambridge Univesrity Press, pp. 55-87.

Clague, D.A., 1987, Hawaiian alkaline volcanism, in Fitton, J.G. and Upton, B.G. (eds), Alkaline Igneous Rocks: Blackwell Scientific Publications, pp. 227-252.

Cohen, B.E., Vasconcelos, P.M. and Knesel, K.M., 2007, ${ }^{40} \mathrm{Ar} /{ }^{39} \mathrm{Ar}$ constraints on the timing of Oligocene intraplate volcanism in southeast Queensland: Australian Journal of Earth Sciences, v. 54, pp. 105-125.

Cohen, B.E., Knesel, K.M., Vasconcelos, P.M., Thiede, D.S. and Hergt, J.M., $2008,{ }^{40} \mathrm{Ar} /{ }^{39} \mathrm{Ar}$ constraints on the timing and origin of Miocene leucitite volcanism in southeastern Australia: Australian Journal of Earth Sciences, v. 55 , pp. $407-418$.

Conrad, C.P., Bianco, T.A., Smith, E.I. and Wessel, P., 2011, Patterns of intraplate volcanism controlled by asthenospheric shear: Nature Geoscience, v. 4, pp. 317-321.

Demidjuk, Z., Turner, S., Sandiford, M., George, R., Foden, J. and Etheridge, M., 2007, U-series isotope and geodynmaic constraints on mantle melting processes beneath the Newer Volcanic Province in South Australia: Earth and Planetary Science Letters, v. 261, pp. 517-533.

Duggan, M.B., Knutson, J. and Ewart, A., 1993, IAVCEI Canberra 1993 Excursion Guide: Warrumbungle, Nandewar, and Tweed Volcanic Complexes: AGSO Record 1993/70, Canberra.

Duncan, R.A. and McDougall, I., 1989, Volcanic Time-Space Relationships, in Johnson, R.W. (ed), Intraplate Volcanism in Eastern Australia and New Zealand: Cambridge University Press, pp. 43-53.

Eggins, S.M., Green, D.H. and Falloon, T.J., 1991, The Tasmantid Seamounts: shallow melting and contamination of an EM1 mantle plume: Earth and Planetary Science Letters, v. 107, pp. 448-462.

Eisele, J., Sharma, M., Galer, S.J.G., Blichert-Toft, J., Devey, C.W. and Hofmann, A.W., 2002, The role of sediment recycling in EM-1 inferred from $\mathrm{Os}, \mathrm{Pb}, \mathrm{Hf}, \mathrm{Nd}, \mathrm{Sr}$ isotope and trace element systematics of the Pitcairn hotspot: Earth and Planetary Science Letters, v. 196, pp. 197212.

Ewart, A., 1982, Petrogenesis of the Tertiary Anorogenic Volcanic Series of Southern Queensland, Australia, in the Light of Trace Element Geochemistry and $\mathrm{O}, \mathrm{Sr}$ and $\mathrm{Pb}$ Isotopes: Journal of Petrology, v. 23, pp. 344-382.

Ewart, A., 1985, Aspects of the mineralogy and chemistry of the intermediatesilicic Cainozoic volcanic rocks of eastern Australia. Part 2: mineralogy and petrogenesis: Australian Journal of Earth Sciences, v. 32, pp. 383413.

Ewart, A., 1989, East Australian Petrology and Geochemistry, in Johnson, R.W. (ed), Intraplate Volcanism in East Australia and New Zealand: Cambridge University Press, pp. 189-246.

Ewart, A. and Grenfell, A., 1985, Cainozoic volcanic centres in southeastern Queensland, with special reference to the Main Range, Bunya Mountains, and the volcanic centres of the northern Brisbane coastal region: Department of Geology, University of Queensland, Papers, v. 11 pp. 1-57.

Ewart, A., Baxter, K. and Ross, J.A., 1980, The Petrology and Petrogenesis of the Tertiary Anorogenic Mafic Lavas of Southern and Central 
Queensland, Australia - Possible Implications for Crustal Thickening: Contributions to Mineralogy and Petrology, v. 75, pp. 129-152.

Ewart, A., Chappell, B.W. and Le Maitre, R.W., 1985, Aspects of the mineralogy and chemistry of the intermediate-silicic Cainozoic volcanic rocks of eastern Australia. Part 1: introduction and geochemistry: Australian Journal of Earth Sciences, v. 32, pp. 359-382.

Ewart, A., Stevens, N.C. and Ross, J.A., 1987, The Tweed and Focal Peak Shield Volcanoes, southeast Queensland and northeast New South Wales: Department of Geology, University of Queensland, Papers, v. 11, pp. 1-82.

Ewart, A., Chappell, B.W. and Menzies, M.A., 1988, An Overview of the Geochemical and Isotopic Characteristics of Eastern Australian Cainozoic Volcanic Provinces, in Menzies, M.A. and Cox, K.G. (eds), Oceanic and Continental Lithosphere: Similarities and Differences. Journal of Petrology, Special Volume, pp. 255-274.

Gaina, C. and Müller, R.D., 2000, Absolute Plate Motion, Mantle Flow, and Volcanism at the Boundary Between the Pacific and Indian Ocean Mantle Domains Since $90 \mathrm{Ma}$, in Richards, M.A., Gordon, R.G. and van der Hilst, R.D. (eds), The History and Dynamics of Global Plate Motions: American Geophysical Union, pp. 189-210.

Green, D.H., Edgar, A.D., Beasley, P., Kiss, E. and Ware, N.G., 1974, Upper Mantle Source for Some Hawaiites, Mugearites and Benmoreites: Contributions to Mineralogy and Petrology, v. 48, pp. 33-49.

Griffin, W.L., Sutherland, F.L. and Hollis, J.D., 1987, Geothermal profile and crust-mantle transition beneath east-central Queensland: volcanology, xenolith petrology and seismic data: Journal of Volcanology and Geothermal Research, v. 31, pp. 177-203.

Grimes, K.G., 1982, Stratigraphic Drilling Report - GSQ Sandy Cape 1-3R: Queensland Government Mining Journal, v. 83, pp. 224-233.

Hawkesworth, J., 1773, An account of the voyages, Volume Three: W. Strahan and T. Cadell, London.

Hunter, R.J., 2004, World Heritage and associative natural values of the Central Eastern rainforest reserves of Australia: New South Wales Department of Environment Climate Change and Water, Sydney, 149 pp. http:// www.environment.nsw.gov.au/protectedareas/CERRAvaluesreport.htm,

Johnson, R.W., 1989, Intraplate Volcanism in Eastern Australia and New Zealand: Cambridge University Press, Cambridge, 395 pp.

Knesel, K.M., Cohen, B.E., Vasconcelos, P.M. and Thiede, D.S., 2008, Rapid change in drift of the Australian plate records collision with Ontong Java plateau: Nature, v. 454, pp. 754-757.

Koppers, A.A.P., Duncan, R.A. and Steinberger, B., 2004, Implications of a nonlinear ${ }^{40} \mathrm{Ar}{ }^{\beta 9} \mathrm{Ar}$ age progression along the Louisville seamount trail for models of fixed and moving hotspots: Geochemistry, Geophysics, Geosystems, v. 5, pp. 1-22.

Kroenke, L.W., Wessel, P. and Sterling, A., 2004, Motion of the Ontong Java Plateau in the hot-spot frame of reference: $122 \mathrm{Ma}-$ present, in Fitton, J.G., Mahoney, J.J., Wallace, L.M. and Saunders, A.D. (eds), Origin and evolution of the Ontong Java Plateau: Geological Society of London, pp. 9-20.

Lister, G.S. and Etheridge, M.A., 1989, Detachment Models for Uplift and Volcanism in the Eastern Highlands, and their Application to the Origin of Passive Margin Mountains, in Johnson, R.W. (ed), Intraplate Volcanism in Eastern Australia and New Zealand: Cambridge University Press, pp. 297-313.

McDonough, W.F., McCulloch, M.T. and Sun, S.-s., 1985, Isotopic and geochemical systematics in Tertiary- Recent basalts from southeastern Australia and implications for the evolution of the sub-continental lithosphere: Geochimica et Cosmochimica Acta, v. 49, pp. 20512067.

McDougall, I. and Duncan, R.A., 1988, Age progressive volcanism in the Tasmantid Seamounts: Earth and Planetary Science Letters, v. 89, pp. $207-220$
McElhinny, M.W., Embleton, B.J.J. and Wellman, P., 1974, A Synthesis of Australian Cenozoic Palaeomagnetic Results: Geophysical Journal of the Royal Astronomical Society, v. 36, pp. 141-151.

O'Reilly, S.Y. and Griffin, W.L., 1985, A xenolith-derived geotherm for southeastern Australia and its geophysical implications: Tectonophysics, v. 111, pp. $41-63$.

O'Reilly, S.Y. and Griffin, W.L., 1987, Eastern Australia - 4000 kilometres of mantle samples, in Nixon, P.H. (ed), Mantle Xenoliths: John Wiley and Sons, pp. 267-280.

Quilty, P.G., 1993, Tasmantid and Lord Howe seamounts: bio-stratigraphy and palaeoceanographic significance: Alcheringa, v. 17, pp. 27-53.

Robertson, G.B., Prescott, J.R. and Hutton, J.T., 1996, Thermoluminescence dating of volcanic activity at Mt Gambier, South Australia: Royal Society of South Australia, Transactions, v. 120, pp. 7-12.

Sharp, W.D. and Clague, D.A., 2006, 50-Ma Initiation of Hawaiian-Emperor Bend Records Major Change in Pacific Plate Motion: Science, v. 313 pp. 1281-1284.

Sun, S.-S., McDonough, W.F. and Ewart, A., 1989, Four Component Model for East Australian Basalts, in Johnson, R.W. (ed), Intraplate Volcanism in Eastern Australia and New Zealand: Cambridge University Press, pp. 333-347.

Sutherland, F.L., 1991, Cainozoic volcanism, Eastern Australia: a predictive model based on migration over multiple 'hotspot' sources, in Williams, M.A.J., De Deckker, P. and Kershaw, A.P. (eds), The Cainozoic of Australia: A Re-appraisal of the Evidence: Geological Society of Australia, Special Publication, v. 18, pp. 15-43.

Sutherland, F.L., 1992, Tasman Sea evolution and hotspot trails, in van der Lingen, G.J., Swanson, K.M. and Muir, R.J. (eds), Evolution of the Tasman Sea Basin: A.A. Blkema, pp. 35-51.

Sutherland, F.L., 1993, Late thermal events based on zircon fission track ages in northeastern New South Wales and southeastern Queensland: Links to Sydney Basin seismicity?: Australian Journal of Earth Sciences, v. 40 , pp. $461-470$.

Sutherland, F.L., Robertson, A.D., Hendry, D.F. and Hollis, J.D., 1990, Xenolith studies from southern Queensland: the lithosphere below volcanic regions, in Finlayson, D.M. (ed), The Eromanga-Brisbane Transect. BMR Bulletin, v. 232, pp. 213-235.

van der Hilst, R.D., Kennett, B.L.N. and Shibutani, T., 1998, Upper Mantle Structure beneath Australia from Portable Array Deployments, in Braun, J., Goleby, B., van der Hilst, R.D. and Klootwijk, C. (eds), Structure and Evolution of the Australian Continent, Geodynamics Series: American Geophysical Union, pp. 39-57.

Vasconcelos, P.M., Knesel, K.M., Cohen, B.E. and Heim, J.A., 2008 , Geochronology of the Australian Cenozoic: a history of tectonic and igneous activity, weathering, erosion, and sedimentation: Australian Journal of Earth Sciences, v. 55, pp. 865-914.

Wellman, P. (1971) The age and palaeomagnetism of the Australian Cenozoic volcanic rocks, Department of Geology: Australian National University, Canberra,

Wellman, P., 1975, Palaeomagnetism of two Mid-Tertiary Basaltic Volcanoes in Queensland, Australia: Royal Society of Queensland, Proceedings, v. 86 , pp. $147-153$.

Wellman, P. and McDougall, I., 1974, Cainozoic igneous activity in eastern Australia: Tectonophysics, v. 23, pp. 49-65.

Willey, E.C., 2003, Urban Geology of the Toowoomba conurbation, SE Queensland, Australia: Quaternary International, v. 103, pp. 57-74.

Willmott, W.F., 2003, Rocks and Landscapes of the National Parks of Southern Queensland: Geological Society of Australia, Queensland Division, Brisbane, $162 \mathrm{pp}$.

Willmott, W.F., 2010, Rocks and Landscapes of the Gold Coast Hinterland: Geological Society of Australia, Queensland Division, Brisbane, 84 pp.

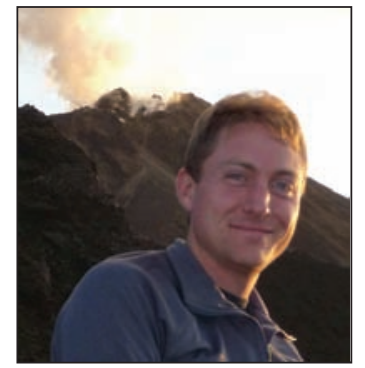

Benjamin E. Cohen obtained his PhD from the University of Queensland in 2007. He specialises in igneous petrology and ${ }^{40} \mathrm{Ar} /{ }^{39} \mathrm{Ar}$ geochronology, particularly with regards to intraplate volcanism in eastern Australia, and the implications for the Cenozoic tectonic history of the continent. In 2010-2011 he also participated in an IODP expedition to the Pacific Louisville seamounts. Other areas of interest include wider applications of chronology in the Earth Sciences. 